\title{
Improvements in docking scoring functions: the physics-based perspective
}

Xavier Barril

\author{
From 7th German Conference on Chemoinformatics: 25 CIC-Workshop \\ Goslar, Germany. 6-8 November 2011
}

Docking is possibly the most widely used technique in structure-based drug design. It is recognized as extremely useful to guide the development of active molecules as well as in virtual screening to identify new leads. But docking is also notoriously imperfect and many aspects need to improve. In this talk I will present our work on two different sources of errors in the docking predictions: protein-ligand interaction potentials and internal energy of the ligands. The use of higher-level calculations offers an opportunity to obtain better quality results and offers a glimpse of the full potential of the technique, but introducing this information back into fast and general scoring functions remains a challenge.

Publish with ChemistryCentral and every scientist can read your work free of charge

"Open access provides opportunities to our colleagues in other parts of the globe, by allowing anyone to view the content free of charge."

W. Jeffery Hurst, The Hershey Company.

- available free of charge to the entire scientific community

- peer reviewed and published immediately upon acceptance

- cited in PubMed and archived on PubMed Central

- yours - you keep the copyright

Submit your manuscript here:

http://www.chemistrycentral.com/manuscript/

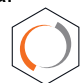

Chemistry Central 